\title{
Sustainable development in higher education: Managing efficiency and effectiveness - a case of Ukraine
}

\author{
Serhii Levchenko ${ }^{1, *}$ \\ ${ }^{1}$ Department of Management, International Humanitarian University, Fontanskaya road, 33, 65009 \\ Odessa, Ukraine
}

\begin{abstract}
This article touches upon an issue of an impact of efficiency and effectiveness, which are the factors that ensuring sustainability of higher educational process in Ukraine. The article analyses the existing definitions of efficiency and effectiveness in the context of higher education, both those provided by the English dictionary, and in scholars' terms. The author of this publication found that many of the authors' definitions of effectiveness coincide in nature, on the basis of which the types of effectiveness were grouped. Also, the article identifies some areas of higher education reform, both Ukrainian and foreign experience. In addition, approaches to assessing the activities of free economic zones in the "TOP-200 Ukraine" and world rankings, in particular, uniRank, QS, NatureIndex, are analysed. The orientation of these ratings on the scientific process, without the orientation on student-centeredness, is revealed and the substantiation on the possibilities to improve both of them in Ukrainian higher education institutions (HEIs) with the orientation on student-centeredness is given, which helps to achieve Goal 4 of Sustainable Development.
\end{abstract}

\section{Introduction}

For the beginning of $21^{\text {st }}$ century, during the rapid technological progress there is an increase in environmental pollution of the planet. Society in all countries of the world faces many global challenges. In order to overcome the global challenges of humanity, the concept of sustainable development was created. It aims at improving the well-being of the world's population, taking into account global human problems, such as economic and gender inequality, health, access to education, greening society, overcoming poverty, developing infrastructure and innovation, and more. To this end, the concept of sustainable development sets 17 goals, which are adopted by the UN [1]. The fourth goal of sustainable development is to provide comprehensive, quality and equitable education and to encourage lifelong learning. Among the tasks to achieve this goal, there was set the one to ensure equal access for men and women to cheap vocational and higher education by 2030. Efficiency and effectiveness of a higher education are also aspects of higher education sustainability.

* Corresponding author: mgu-center@ukr.net 
As of the 2019/2020 academic year, there are 281 higher education institutions (HEIs) in Ukraine [2]. A number of literature sources talk about their low efficiency. In the modern scientific literature, there are a large number of definitions of effectiveness, analysing which it can be concluded that there is no single understanding of effectiveness in the Ukrainian scientific sources. Currently, Ukraine is reforming its higher education system. According to the Strategy for the Development of Higher Education in Ukraine for 2021-2031 (the Ministry of Education and Science), "the main problem for developing higher education is the lack of long-term strategy of socio-economic development of Ukraine, which complicates the creation of a model of higher education" [3]. That is, the Ministry of Education and Science recognizes that the activities of the HEIs in Ukraine are not effective, which leads to another problem of determining the effectiveness in the context of higher education.

\section{Methods}

This article is based on the meta-analysis of the Ukrainian and foreign publications dedicated to the problems of efficiency and effectiveness in a context of higher education, based on the statistic data, a doctoral dissertation, and articles from Research Gate database. Full methodology could be seen at Fig. 1.

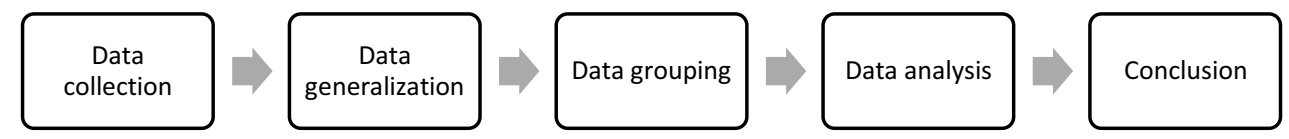

Fig. 1. The methodological process of making a review.

Source: Developed by the author.

On the stage of data collection, there were gathered the statistical data from open sources, related to the higher education, reviews from ResearchGate database, a doctoral dissertation dedicated to a problem of performance management in higher education, handbooks, English dictionaries and the interview of the Head of the Secretariat of National Agency of Quality Assurance in a Higher Education. On the next stage, there were analysed the main ideas of the collected data. On the stage of grouping, the data was sorted theoretically and statistically. Based on this, there were found positive and negative sides of each data group. Therefore, there was made a conclusion about efficiency and effectiveness of higher education in Ukraine.

\section{Literature review}

The study of effectiveness in the context of higher education has received attention of researchers; therefore, approaches to determining effectiveness differ. However, these definitions depend on feedback and one's own vision of the stakeholders' effectiveness, i.e., there are many definitions of effectiveness that are used depending on the goals.

According to Kanwal, efficiency can be described as the collective contribution of internal and external stakeholders [4]. However, in her work, Kanwal uses the term "performance" instead of "efficiency". Melnyk noted that the concept of efficiency is determined by two characteristics: the involvement of a valid and proven benchmark result (benchmark), which aims at efficiency and is based on the ratio of supply and demand of efficiency [5]. Krause defines efficiency as the degree of achieving certain goals, or the long- 
term result of the goals set [6]. From this definition it follows that the parameters of efficiency are not clearly defined; they are individual and depend on the organization management.

Among the Ukrainian authors, the most popular definition of efficiency is the ratio of effect to cost result. S. Mocherny and O. Ustenko adhere to this definition. According to B. Zhniakin and V. Krasnova, "efficiency is the ratio of the result (effect) with the costs that caused this effect" [7]. In essence, these two statements duplicate each other. Also, Mocherny and Ustenko distinguish between two types of efficiency: economic and social. According to them, "Social efficiency is the conformity of the economic activity results to the basic social needs and goals of society, the interests of the individual. Economic efficiency means achieving the greatest results at the lowest cost of living and tangible labour "[8]. Svatyuk, Mironova and Mironov, in the context of distance education, distinguish between four types of efficiency: socio-pedagogical, organizational, technological and economic [9].

In foreign sources, there is no unambiguous synonym for the Ukrainian word "efficiency". For example, the Oxford English Dictionary gives the following definitions:

- efficiency is "the quality of doing something good, without wasting money or time" [10];

- effectiveness is "the fact of creating the expected or desired result; the fact of creating a successful result "[10];

- efficacy is "the ability to get the desired result" [10].

However, the Oxford Dictionary does not specify the interpretation of "performance" as an analogue of efficiency. Dictionary.com defines performance as "the way or efficiency with which something responds or fulfils its intended purpose" [11]. In this case, it can be referred to as efficiency, therefore, it can be concluded that in English sources performance and efficiency are synonymous and refer to the reduction of monetary costs, and effectiveness and efficacy are aimed at defining the effect as an opportunity to obtain an aimed result.

According to O. Velychko [12], effectiveness is a cumulative value and emphasizes the need to reform the Ukrainian higher education system. In particular, in his opinion, the task of HEIs is to promote the interest of HEIs' teachers in the scientific work, because the study shows a low level of interest. Also, he proposed a mechanism of increasing efficiency of the faculty's scientific activity by external stimulation. In particular, he proposes that the rating of HEIs should be published by the National Agency for Quality Assurance in Higher Education on the basis of the accreditation process.

According to K. Szadkowski [13], for successful adaptation, free economic development should be carried out in 6 areas: ontology, form of ownership, policy, strategy of state regulation, advantages of free economic education and financing. According to the ontological direction, HEIs should answer the questions "What exists in HEIs and how does it exist?", "What ideas can be seen through the prism of the HEIs' scientific activity?" In politics (both state and local), it involves defining the goals of higher education, values, defining conflicts and their parties. In the direction of the form of ownership, the following questions should be answered: "Who owns the institution?", "Who controls the institutions?", "Who owns the products?", "What is the turnover of the products of the institution?" State regulation should provide a transparent and democratic educational process while ensuring the autonomy of HEI. The HEI should also have clear advantages, according to which this HEI will be popular among all stakeholders. Regarding funding, the HEI should decide on the following questions: "What is funded and by whom?", "Who and how finances institutions?" and "Who pays for higher education and research?"

According to the head of the NAQA secretariat M. Vynnytskyi [14], the insignificant presence of HEIs in the world rankings is caused by the fact that such rankings are formed on the basis of scientific and not educational activities. Also, he differentiates between such concepts as "researcher" and "teacher", because, in his words, a good researcher and a good teacher are two different persons. 
Based on the literature review, it is advisable to harmonize the concepts that are related to the effectiveness of foreign sources with Ukrainian ones. We propose to use such concepts as cumulative efficiency and optimization efficiency. Cumulative efficiency (effectiveness) is the fact of creating a desired or successful result. The effect of cumulative efficiency in the context of higher education is the cumulative contribution of internal and external stakeholders to the quality of the educational process. It follows from this definition that cumulative efficiency is closely linked to the concept of "quality". Optimization efficiency (efficiency) is the ability to minimize the cost of producing something or carrying out a process. In the context of higher education, optimization efficiency is the ability to minimize the costs of the educational process by HEI. Both of them have its own functions that could be seen at Fig. 1

Efficiency (optimization)
- Improving the qualification level of
scientific and pedagogical staff
- Reduce training costs
- Commercialization of HEls
- Reducing the number of HEls

Effectiveness (cumulative)
- Providing a comfortable learning
environment
- Focus on innovation in the
educational process
- Introduction of mechanisms for
sustainable development as a
strategic goal of the HEl

Fig. 2. Functions of efficiency and effectiveness in a context of higher education.

Source: developed by the author.

As could be seen in Fig. 2, these concepts are not synonymous, but they are closely interrelated and do not contradict each other, as it may seem at the first glance. With improper management of the higher education system at the state level, the reduction of funding HEIs can lead to a significant reduction in the quality of education. However, it is the optimization efficiency that is of greater interest, given the large number of HEIs in Ukraine.

According to Ukrstat, the number of higher education institutions has changed little over the last five years. On 2019/2020 academic year in Ukraine, there were 281 HEIs. Fig. 3 presents the total number of higher educational institutions in Ukraine in the period 2010/11 - 2019/2020 academic year according to the Ukrainian State Statistics Service [2].

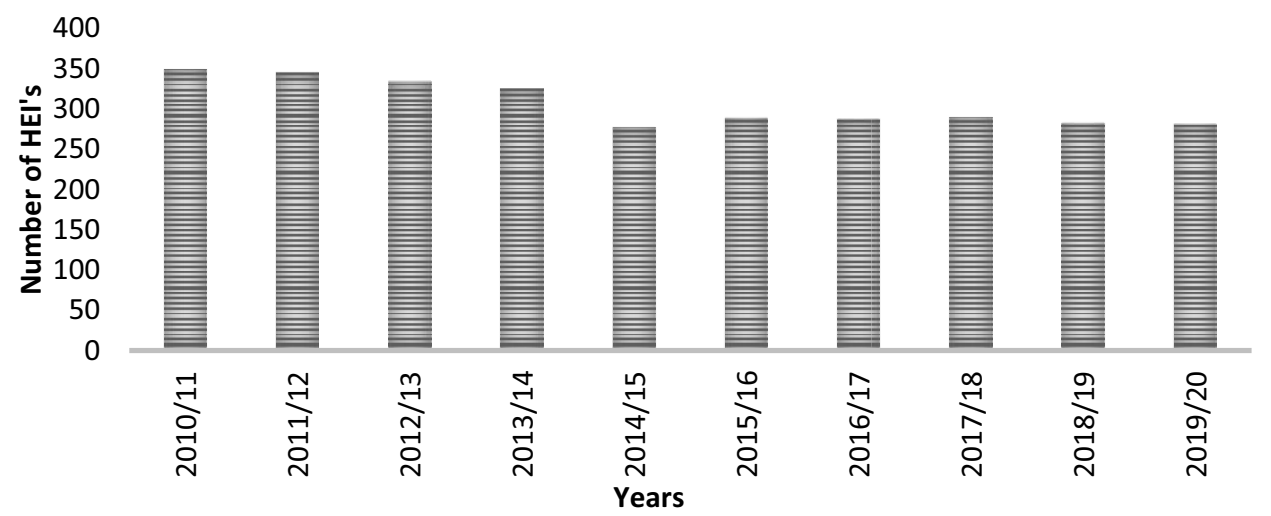

Fig. 3. The number of HEIs in Ukraine.

Source: compiled by the author based on the data [1]. 
As could be seen in Fig.3, the most significant reduction in the number of HEIs occurred in 2014/15 academic year. The reason for this reduction was the occupation of the Autonomous Republic of Crimea and certain regions of Donetsk and Luhansk regions. Such a reduction in the number of HEIs was political in nature, not optimistic. However, according to Webometrics [15], as of July 2020, there were 317 HEIs in Ukraine, of which 33 ranked from 1001 to 5000, and 77 - from 5001 to 10000 . This allows concluding that Ukrainian higher education is not competitive in comparison with other countries, despite a big amount of HEIs, and therefore is not effective in terms of both cumulative and optimization effect. In order to increase the optimization effect, there are private HEIs which are aimed at making a profit. Figure 4 shows the number of HEIs in some European countries.

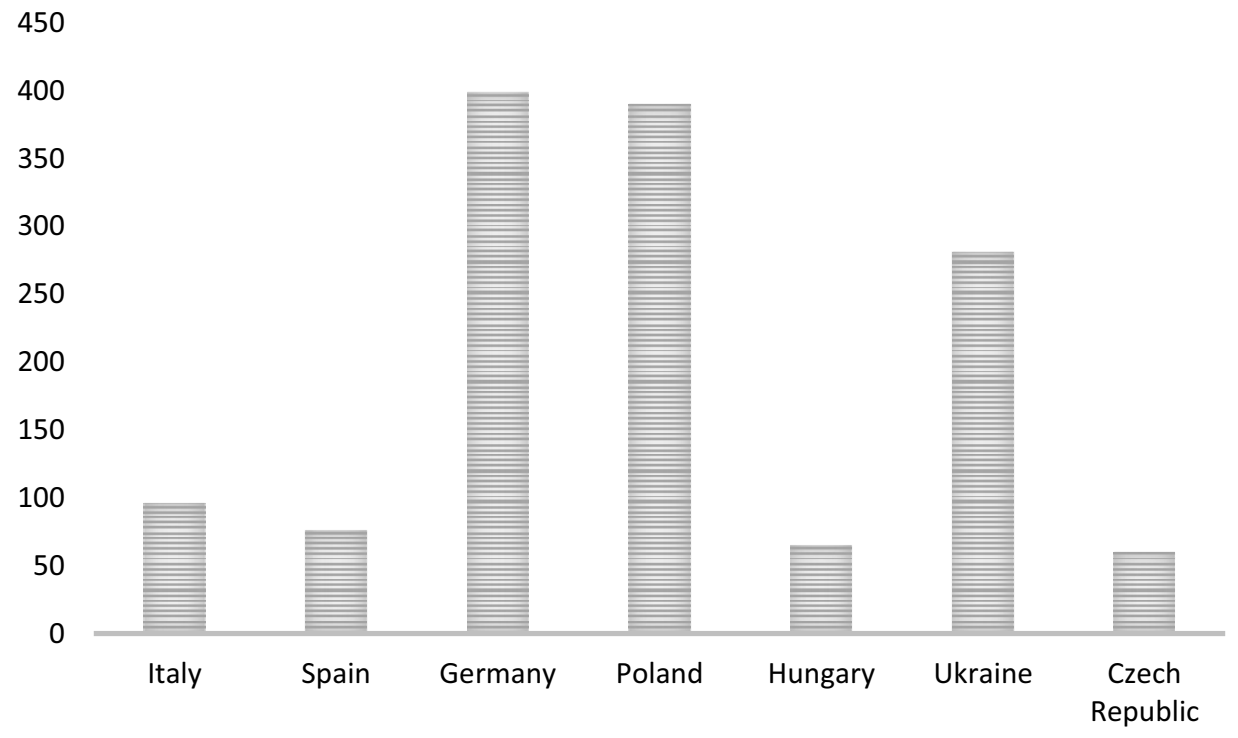

Fig. 4. The number of universities in some European countries.

Source: compiled by the author based on the data $[2,16,17,18,19,20]$.

It can be seen in Fig. 4, among the selected European countries, the larger number of HEIs is only in Germany and Poland. However, the study shows, in general, the low efficiency of Polish HEIs [21]. Among the large number of German HEIs, 3 are in the first hundred, 6 rank from 101-200, 28 - 201-500, 20 - 501-1000, 72 - 10001-5000 and $129-$ 5001-10000. Such indicators allow considering the German higher education system effective in both aspects. Compared to the number of HEIs in Ukraine, the German ones appear to be more effective.

In Ukraine, there is a rating of TOP-200 Ukraine, which assesses the activities of local HEIs. It is carried out by the Centre for International Projects "Euroeducation" in partnership with the international group of experts IREG Observatory on Academic Ranking and Excellence [22]. This rating is based on 10 indicators provided in table 1.

After analysing these indicators, it could be concluded that some of them are formal in nature. In particular, uniRank refers to organizations related to the accreditation of educational processes, the Ministry of Foreign Affairs, the Ministry of Health, the Ministry of Economy and Development, the Ministry of Culture. However, uniRank does not refer the National Agency for Quality Assurance in Higher Education to organizations accrediting educational process in Ukraine, as defined by the relevant Regulations [23, 24]. In the QS rating [25], there are only seven among the Ukrainian HEIs. A similar situation can be seen in the Nature Index rating, where there are only 12 among the HEIs of Ukraine [26]. On the 
other hand, the low presence of Ukrainian HEIs in such international rankings makes it possible to state that Ukrainian higher education is poorly recognized by some rankings.

In addition, the rating of TOP-200 Ukraine evaluates the quality of applicants' training taking into account only the results of all-Ukrainian competitions and research papers, the number of active students who participate in these activities when assessing HEIs. However, the TOP-200 Ukraine does not reflect the connection with external stakeholders/employers in educational activities and does not take into account student-centeredness, which is one of the priorities of the Ukrainian higher educational system.

Table 1. Indicators of calculations of a place in a TOP-200 rating in Ukraine.

\begin{tabular}{|c|c|c|}
\hline The weight of the indicator & Coefficient & Estimated activity \\
\hline QS World University Rankings & 0.145 & Academic activity \\
\hline Scopus & 0.145 & Science-publishing activity \\
\hline Webometrics & 0.145 & $\begin{array}{l}\text { Evaluation of scientific } \\
\text { achievements of the universities } \\
\text { through the analysis of the } \\
\text { Internet sites }\end{array}$ \\
\hline $\begin{array}{l}\text { Participation in the Erasmus }+ \\
\text { programs of the European Union }\end{array}$ & 0.145 & International mobility \\
\hline Nature Index & 0.10 & $\begin{array}{l}\text { Quotation of scientific } \\
\text { publications in the high-ranking } \\
\text { scientific studies }\end{array}$ \\
\hline UniRank & 0.10 & $\begin{array}{l}\text { The quality of representation and } \\
\text { popularity of HEI in the Internet } \\
\text { space based on independent } \\
\text { webometric indicators }\end{array}$ \\
\hline $\begin{array}{l}\text { Results of the All-Ukrainian } \\
\text { Student Olympiads } 2018 / 2019 \text { and } \\
\text { Competitions of Science Robots } \\
2019 / 2020 \text { (for the sum of points) }\end{array}$ & 0.055 & $\begin{array}{l}\text { The quality of the training of } \\
\text { students }\end{array}$ \\
\hline $\begin{array}{l}\text { Prizes of the President of Ukraine } \\
\text { and the Verkhovna Rada of } \\
\text { Ukraine for young researchers }\end{array}$ & 0.055 & Educational and scientific work \\
\hline $\begin{array}{l}\text { The number of patents received by } \\
\text { scientists of the university in } 2020\end{array}$ & 0.055 & Inventive activity \\
\hline $\begin{array}{l}\text { Average weighted value for HEIs' } \\
\text { ratings by the number of } \\
\text { applications submitted by entrants } \\
\text { and the average competitive score } \\
\text { in } 2020\end{array}$ & 0.055 & $\begin{array}{l}\text { Attractiveness of the university } \\
\text { for entrants }\end{array}$ \\
\hline
\end{tabular}

*Source: [22]. 


\section{Results and discussion}

Based on the literature review, among the Ukrainian and foreign scholars there is no consensus on defining the effectiveness and efficiency of higher education. A review of other literature has also shown that some scholars confuse the terms "efficiency", "effectiveness" and "performance". The effectiveness of higher education is ambivalent. On the one hand, it can be considered as the combined influence of all stakeholders to obtain the desired or expected result (effectiveness), and on the other hand, it is to minimize the cost of the educational process. Indeed, it may seem that these concepts contradict each other, which can have a negative impact on managing HEI, as cost reduction can be irrational, so this process must also take into account the impact on the quality of the educational process.

Another problem with the efficiency of higher education in Ukraine is the large number of HEIs in comparison with other European countries. However, only a few of them are recognized in world rankings. To assess the HEIs' activities, there is a list of "TOP-200 Ukraine", which, in our opinion, does not take into account student-centeredness when calculating the HEI ratings. Also, some data that are taken into account when calculating the HEI rating are not objective; in particular, the calculations of uniRank, which incorrectly determine the organizations related to the accreditation of the educational process in Ukraine. The quality of applicants' training, according to the "TOP-200 Ukraine", is also assessed impartially, because the sample of assessment in this case will be single, not mass compared to other applicants. Instead, we propose to assess the quality of applicants' training on the average score of the diploma supplement, because, thus, the sample will be much larger, which will allow assessing the quality of training more accurately, because the assessment will be based on the quality of training of all applicants. However, in this case there is a risk of overestimating applicants. In our opinion, the quality control of training should be carried out blindly to ensure the objectivity of the examiner, as during the external evaluation. Therefore, in the perspective of further research to assess the effectiveness of Ukrainian HEIs, the paper proposes to pay attention to the relationship between institutions and employers and student-centeredness, based on which the appropriate evaluation criteria are introduced. In addition, it is considered appropriate to introduce evaluation criteria, which are related to the employment of HEIs' graduates. Such an approach will allow a more objective assessment of the HEI's effectiveness. Also, the issue of distinguishing between teachers and researchers remains controversial. The impact on the HEI's effectiveness should be exerted not only by scientific activities, but also by educational ones, and educational activities should have a much higher coefficient than scientific ones. Receiving a high level of student-centeredness will help to each HEI to achieve Goal 4 of Sustainable Development more than orientation on research, because Bachelor's and Master's degrees are not defined as educational-researching. In other words, top management of HEI should create comfortable conditions for every student to get a competitive higher education for achieving Goal 4.

\section{Conclusion}

Efficiency and effectiveness are the aspects of sustainability in a context of higher education. On the one hand, there is a term which is synonymic to quality (effectiveness). This term is more important to stakeholders, both external and internal, because their aim is to get knowledge. On the other hand, there is a term 'efficiency', which means an ability to get an aimed or desired result with less time and effort. The effort in a context of higher education is the training cost. Reducing costs for the higher education may degrade the quality, and, hence, reduce the effectiveness of higher education in case of wrong actions on the state and systemic levels. The Ukrainian ranking system "Top 200 Ukraine" takes into account only 
research activities, neglecting educational. The only researching-educational level in Ukrainian higher educational system is the third one ( $\mathrm{PhD}$ student). Other higher educational levels are not defined as researching. Thus, this ranking does not correlate with educational aspects and also does not take into account a student's opinion about the educational process. The term 'effectiveness' is highly related to Goal 4 of Sustainable Development. In a perspective, there should be developed a new ranking system for HEIs, which would consider criteria related to the educational process and feedback from the stakeholders.

\section{References}

1. The 17 goals, https://sdgs.un.org/ru/goals (2021)

2. Higher Educational Institutions, http://www.ukrstat.gov.ua/operativ/operativ2005/osv_rik/osv_u/vuz_u.html (2020)

3. Strategy of a higher education development for 2021-2031 years. http://www.reform.org.ua/proj_edu_strategy_2021-2031.pdf(2020)

4. S. Kanwal. Impact of performance management system on organisational performance of higher education institutions: a case study of Pakistan (Doctoral dissertation, University of Salford), 249 p. (2018)

5. S. Melnyk, U. Bititci, K. Platts, J. Tobias, B. Andersen. Management Accounting Research, 25(2), 173-186. (2014)

6. O. Krause, Performance Management - Eine Stakeholder-Nutzen-orientierte und Geschaftsprozess-basierte Methode, Technische Universitat, 322. (2005).

7. B. Zhnjakin, V. Krasnova. Business Economics textbook for HEI's, 160. (2009)

8. S. Mochernyj, O. Ustenko (2005) Fundamentals of Entrepreneurship Handbook. 280, (2005)

9. O. Svatjuk, Ju. Myronov, M. Myronova. Problems of application of information technologies by law enforcement structures of Ukraine and higher educational institutions with specific conditions of study, 215-219, https://kerivnyk.info/2017/12/svatiuk-myronov-edn.html. (2017)

10. Oxford Learner's Dictionaries. https://www.oxfordlearnersdictionaries.com (2021)

11. Dictionary.com. https://www.dictionary.com (2021)

12. O. Velychko, L. Velychko, M. Kharytonov. Social Sciences, 7(8), 138. (2018)

13. Szadkowski, K. Higher Education, 78(2), 241-255. (2019)

14. Vynnycjkyj: Ukrajinsjkyj bakalavrat mozhe daty foru Zakhidnij maghistraturi. https://life.znaj.ua/387552-vinnickiy-ukrajinskiy-bakalavrat-mozhe-dati-foru-zahidniymagistraturi?fbclid=IwAR34J2_bMYmbq7D9joFzeWPRk07BdaHhMK7DKIZuZ18h BYfGzqqREzb5xFc (2021)

15. Countries arranged by Number of Universities in Top Ranks. https://www.webometrics.info/en/distribution_by_country (2021)

16. Free Apply - World's Largest University Catalog. Available at: https://freeapply.com/en

17. Destination Guides: Study in Spain https://www.topuniversities.com/where-tostudy/europe/spain/guide (2021)

18. HRK German Rectors' Conference. The Voice Of The Universities https://www.hrk.de/hrk-at-a-glance/ (2021) 
19. Universities in Poland. Available at: https://www.unipage.net/en/universities_poland. (2021)

20. Universities in the Czech Republic. https://www.unipage.net/en/universities_czechia. (2021)

21. Brzezicki, Ł. Gospodarka Narodowa. The Polish Journal of Economics, 304(4), 33-51. https://doi.org/10.33119/GN/128218 (2020)

22. Ranking of universities in Ukraine "Top200 Ukraine"

http://www.euroosvita.net/index.php/?category=1\&id=6868 (2021)

23. Ukrainian Higher Education-related Organizations, https://www.4icu.org/institutions/ua/ (2021)

24. Ukraine's law: On Amendments to the Law of Ukraine "On Higher Education" Concerning the National Agency for Quality Assurance in Higher Education (2016)

25. QS World University Rankings Available at:

https://www.topuniversities.com/university-rankings/world-university-rankings/2021 (2021)

26. 2021 tables: Institutions - academic https://www.natureindex.com/annualtables/2021/institution/academic/all/countries-Ukraine (2021) 